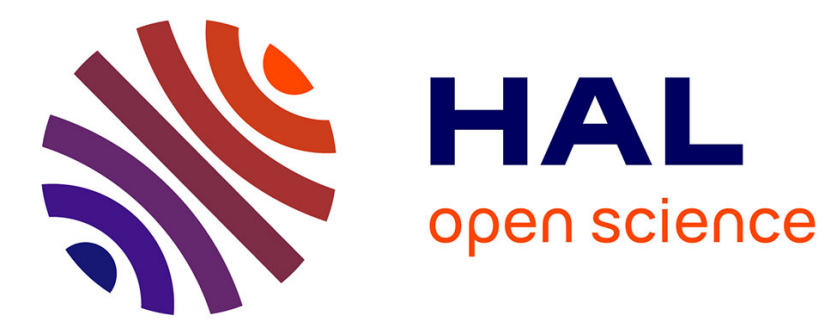

\title{
On the cluster $*^{*}$ sr- in Sino-Tibetan \\ Guillaume Jacques
}

\section{To cite this version:}

Guillaume Jacques. On the cluster *sr- in Sino-Tibetan. Journal of Chinese Linguistics, 2015, 43 (1), pp.215-223. 10.1353/jcl.2015.0001 . halshs-01287468

\section{HAL Id: halshs-01287468 \\ https://shs.hal.science/halshs-01287468}

Submitted on 13 Mar 2016

HAL is a multi-disciplinary open access archive for the deposit and dissemination of scientific research documents, whether they are published or not. The documents may come from teaching and research institutions in France or abroad, or from public or private research centers.
L'archive ouverte pluridisciplinaire HAL, est destinée au dépôt et à la diffusion de documents scientifiques de niveau recherche, publiés ou non, émanant des établissements d'enseignement et de recherche français ou étrangers, des laboratoires publics ou privés. 


\title{
On the cluster *sr- in Sino-Tibetan*
}

\author{
Guillaume Jacques
}

March 13, 2016

\begin{abstract}
This paper presents a critical overview of previously proposed etymologies involving the initial cluster * $s r$ - between Chinese and other Sino-Tibetan languages. It puts forth one new etymology, which confirms the simplification of the cluster * $s r$ - to $s$ - in Kiranti and the preservation of this cluster in Rgyalrong languages.
\end{abstract}

Keywords: Kiranti, Rgyalrong, Japhug, Tibetan, clusters

\section{Introduction}

The Middle Chinese 生 shēng initial consonant $s$, which originates from Old Chinese * $s r$ - in all modern systems of reconstruction, ${ }^{1}$ is attested in a words of Sino-Tibetan origin, and corresponds to onsets either preserving a fricative $+/ \mathrm{r} /$ cluster or originating from one. Thus, * sr appears to be one of the few consonant clusters uncontroversially reconstructible to protoSino-Tibetan.

In this paper, we first discuss previously proposed etymologies, and present the known correspondences of * $s r$ in languages other than Chinese. Second, we present a new etymology and discuss its significance for the conditioning of the sound laws in individual languages.

\section{Previous comparisons}

Only three Chinese words with initial * $s r$ - correspond to forms that are widespread in the rest of the family and can be solidly reconstructed with initial * $s r$-clusters. They were first proposed by Benedict (1972).

\footnotetext{
"Old Chinese follows Baxter and Sagart 2014's system, Middle Chinese is in an IPA transcription based on Baxter (1992), and Tibetan is transcribed according to Jacques (2012). I would like to thank Wolfgang Behr, Gong Xun, Nathan Hill and Laurent Sagart for useful comments on previous versions of this paper.

${ }^{1}$ Some reconstruction models, such as that of Baxter and Sagart (2014), allow more complex clusters such as ${ }^{*} s \mathrm{~N}$ - where ${ }^{*} \mathrm{~N}$ is a nasal with $s$ as outcome in Middle Chinese. However, even in the case of these cluster an intermediate stage ${ }^{*} \mathrm{NN}-\rightarrow{ }^{*} \mathrm{sr}-\rightarrow \varepsilon^{-}$- has to be postulated.
} 
The first such etymon is the word 虽 *srik $\rightarrow$ sit 'louse', which can be compared to Tibetan cig, Japhug zrury and Limbu sir. All words in this cognate set share the same meaning, and there is little doubt that they are related.

The second comparison is Chinese 色 "srak $\rightarrow$ sik 'colour, sex, shame',

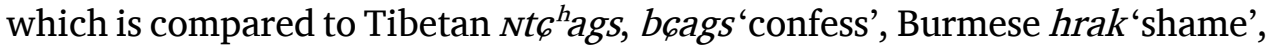
Japhug tr-zгав 'shame'. This comparison is however less convincing from the point of view of semantics, and in the case of Tibetan, philology suggests that the meaning 'confess' is secondary, and evolved from 'declare', the meaning attested in its oldests attestation, the bilingual Sino-Tibetan treaty incription (example 1, translation after Li and Coblin 1987: 40,80), where bcags corresponds to Chinese 稽告 'make known, explain, declare'.

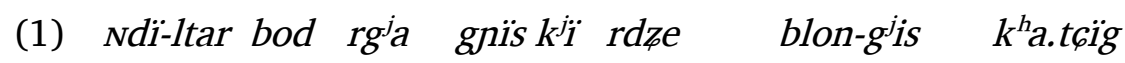
this-like Tibet China two gen sovereign minister-erg together bags mnah bor-te pst:declare oath pst:throw-conv

Thus the sovereigns and the ministers of both Tibet and China together declared and swore an oath. (Sino-Tibetan Treaty, West face, 1. 71-72)

The third one is 生 * $N$-sren $\rightarrow s æ \eta$ 'live, alive', corresponding to Burmese hra ${ }^{2}$ 'alive' and other comparanda (see STEDT \#71). This root has no cognate in Tibetan or Rgyalrong languages.

Other comparisons of Old Chinese "sr-have been proposed by Coblin (1986) in particular, but they are restricted to Tibetan comparanda, and involve words with the onset $s r$-in Tibetan. Nearly all such comparisons can be shown to be invalid for various reasons. ${ }^{2}$ The only promising such correspondence is 侽 " $s r^{\uparrow} e \eta \rightarrow s æ \eta$ 'sister's son' with Tibetan srip.mo 'sister' (the vowel correspondence is a consequence of Dempsey's law, see Hill 2014b).

The double correspondence * $s r$ - to $s r$ - or 6 - in Tibetan suggests that two proto-onsets must be reconstructed here: *so- $r$ - with a reduced vowel yielding $s r$-, while the actual cluster * $s r$ - changes to 6 -, perhaps through a stage $*[s] .{ }^{3}$

\footnotetext{
${ }^{2}$ The comparison of Chinese 率 * $s$-rut $\rightarrow s$ wit 'rule' to Tibetan srid 'government' is problematic for several reasons. The vowel correspondence is not a match (Gong 1995), and the Chinese verb is obviously related to 律 * $r u t \rightarrow$ lwit 'law, rule': the $s$-is here denominal. On the etymology of 律 * rut, see Sagart (2014).

The only other comparison, 產 " $s-\not \eta r^{S} a r ? \rightarrow \mathcal{E} n^{x}$ 'produce' to Tibetan srel 'bring up', which appears possible on the basis of Middle Chinese, is to be ruled out once Old Chinese reconstruction is taken into account.

${ }^{3}$ Note that the causative $s$-forms of $r$-initial verbs in Tibetan is always $s r$-, never 6 -.
} 


\section{A new example of proto-Sino-Tibetan * $s r$}

All Rgyalrong languages share a common word for '(plant) root' attested by Japhug tr-zrrm 'root', Situ -srám and Zbu -rzám. It is an inalienably possessed noun with indefinite possessor prefix $t \gamma$ - (on which see Jacques 2014a: 4-5), and can be reconstructed as proto-Rgyalrong *srem.

While some possessed nouns in Rgyalrong languages can derive from verb without any nominalization affix (see Jacques 2014a: 3-7), it is not the case for this noun, as no corresponding verb is found in any Rgyalrongic language.

Japhug has a variant - srrm which refers to the meaning 'root' in a more abstract sense of 'family lineage', as illustrated by the following example:

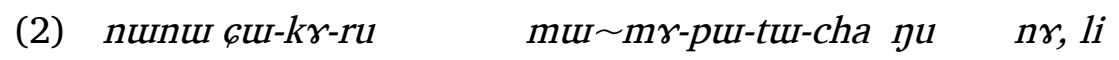
dem transloc-inf-bring cond $\sim$ neg-ipfv-2-can fact:be lnk again $n \gamma$-srrm $n \gamma$-srob ma me 2sg.poss-root 2sg.poss-life apart.from fact:not.exist If you cannot bring it here, again, there is only your family and your life (for you to lose). (Slobdpon2, 207)

This restricted meaning in a context involving a king and his subjects suggests that -srrm in Japhug is not inherited: it is borrowed from Situ Rgyalrong, which was the language of the local chieftain. ${ }^{4}$ Note that borrowings from Tibetan, such as -srob 'life' from srog have $s r$ - in Japhug corresponding to Tibetan $s r-$, not $z r-$ as in the inherited vocabulary. ${ }^{5}$

Apart from this example, voicing of $s-$ in Japhug in this cluster and metathesis in Zbu is completely regular.

In Kiranti, we find a noun *sam attested by Khaling $s \bar{\varepsilon} m$ 'root' (personal fieldwork), Yakkha sam 'root', Kulung sam 'root' (Kongren 2007, Tolsma 2006). The correspondence of Kiranti initial *s- to Japhug $z r$-'louse' is the same of that in the noun 'louse' (Japhug zrury vs Kulung $s i$ ).

A search in STEDT reveals no similar form in any other Sino-Tibetan language. However, this word is phonologically comparable with Chinese 參 shēn (Middle Chinese sim). The character 參 has several readings, but Middle Chinese sim is associated with two meanings: one of the 28 constellations, and rhizomous medicinal plants such as Ginseng (still called in modern Chinese 人參 rénshēn). The earliest attestation of the use of 參 sim for a medicinal plant goes back to the Western Han dynasty, and some scholars have argued for an earlier date (for instance Xu 2011, Sun 1992).

Baxter and Sagart (2014: 75) reconstruct * srum for this character reading, but no evidence either from loanwords or phonetic series rule out the

\footnotetext{
${ }^{4}$ Tusi 土司, in Japhug rfrlpu from Tibetan $r g^{j} a l . p o$ 'king'.

${ }^{5}$ The only potential Tibetan borrowing with $z r$-is zrrntcuu 'bean' from Tibetan sran(.ma) 'bean' (with the native diminutive suffix -tcur), though it cannot be excluded that this word is a cognate between Japhug and Tibetan.
} 
reconstruction *srom, which is the one adopted by other scholars (Schuessler 2009). Old Chinese * srom is a perfect match for proto-Rgyalrong * srem and proto-Kiranti *sam (as shown by Gong 1995 and Hill 2012, Old Chinese *o regularly corresponds to $a$ in Tibetan and other languages).

Chinese has innovated the noun 根 * $[k]^{5} \partial[n]$ 'root', relegating the inherited word 參 *srom to rhizomous medicinal plants.

\section{Loss of *-r-?}

In addition to the correspondences seen in section 2, comparisons where Chinese * $s r$ corresponds to $s$ in other languages have been proposed (in particular by Coblin 1986). Most of these examples either represent more complex correspondences (髟 * $s r^{\Upsilon}$ am $\rightarrow s æ m$ 'hair' corresponds to $s$ in some languages, and to an affricate in others, as in Burmese cham $^{3}$ 'hair') or are spurious. $^{6}$

Possible examples of the correspondence * $s r: s$ include the following:

- 殺 *srat $\rightarrow s \varepsilon t$ 'kill' with Tibetan gsod, bsad 'kill', Japhug sat'kill' etc. (on the vocalism of this word in Chinese, see Baxter and Sagart 2014: 214)

- 沙 * $s r^{\text {I}} a j \rightarrow s æ$ 'sand' with Tibetan $s a$ 'place' (see Hill 2014a concerning the rhyme correspondence).

- 欶 * $s r^{\text {S}} O k \rightarrow$ sæwk 'suck, drink' with Burmese sok'drink'. If this comparison is valid, the original meaning probably was 'sip, suck', 'drink' being a parallel innovation in both languages.

The only attempt to explain the double correspondence of Chinese * $s r$ - to other languages is Handel (2002: 25). According to Handel, original PST * $s r$ changed to $s$ in non-Chinese languages ('Tibeto-Burman') before nonfront vowels. This phonological solution has the merit of simplicity, and, if true, provides a common phonological innovation to all languages besides Chinese (the only one that has been explicitly proposed in print apart from the merger of * $a$ and * $\partial$, on which see Gong 1995, Handel 2008).

However, examples such as 色 *srok 'colour, shame' or 參 *srom 'rhizome' refute Handel's theory, as they show that the conditioning factor that he proposed is not valid. There are three possibilities to account for the examples above.

First, it is possible that Handel is basically right, but that the conditioning is more restricted than he proposed: * $s r$ - is simplified to $* s$ - in languages other than Chinese only before *a (and perhaps * $o$ ), not before

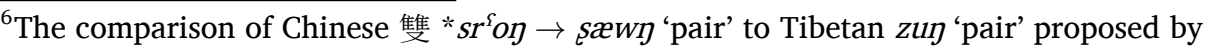
Coblin is impossible as Tibetan $z$ originates from pre-Tibetan ${ }^{*} d z$, see Hill (2014c).
} 
other non-front vowels such as * $*$. If confirmed, this would be another piece of evidence that the merger of * $a$ and * $\partial$ is not a common innovation of non-Chinese languages (contra Gong 1995 and Handel 2008; see also Hill 2014a and Jacques 2014b: 75-6 for additional evidence of the preservation of the contrast in Lolo-Burmese and Tangut respectively). However, it would also constitute a potential common innovation for Sino-Tibetan languages other than Chinese.

Second, the * $r$ - could be secondary in Chinese. As proposed by Sagart (1999) (see also Baxter and Sagart 2014: 57-8), an infix *- $r$ - is reconstructible in Old Chinese, an alternative explanation is to consider Chinese here to be innovative in these three example. In this alternative view, the three examples above represent infixed forms, while the original base forms without infix have been lost. Thus, there would no need to look for a phonological conditioning of this correspondence.

Third, an alternative possibility is that the present models of Old Chinese reconstruction (including Starostin 1989, Schuessler 2009 and Baxter and Sagart 2014) overestimate the quantity of syllables with medial or prefixed $* r$ - in Old Chinese by overgeneralization. In all modern systems of reconstruction, * $-r$ - is reconstructed for all syllables with either second division rhyme, chongniu 3 and/or retroflex initials in Middle Chinese. While it has been convincingly demonstrated that clusters in * $r$ - is indeed one possible origin for these syllables (Yakhontov 1961), there is no definite proof that * $r$ - should be reconstructed in all cases.

As a measure of comparison, over $20 \%$ of syllables in Old Chinese as reconstructed by Baxter and Sagart (2014) contain a preinitial or a medial ${ }^{*} r$, while in Japhug and Tibetan, where consonant clusters including $r$ are attested, we only find respectively $12 \%$ and $16 \%$ of syllables with noninitial $r$.

Given the limited number of reliable comparisons illustrating the correspondences at hand, it is too early to argue which of these three possibilities is the most probably, but each deserve to be investigated in detail.

\section{Conclusion}

The contribution of this paper is twofold. First, it provides a critical overview of previously proposed etymologies involving the onset *sr-in Old Chinese, and shows which etymologies are possible and which should be discarded, on the basis of philological and comparative data.

Second, it shows a new example of proto-Sino-Tibetan * $s r$-, and in particular the second comparison including Kiranti languages. It confirms that proto-Sino-Tibetan ${ }^{*} s r$-is simplified to ${ }^{*} s$-in proto-Kiranti. This work also contributes to the research on Sino-Tibetan subgrouping by exploring to what extent the correspondences at hand provide evidence for common 
innovations of non-Chinese Sino-Tibetan languages ('Tibeto-Burman').

\section{References}

Baxter, William H., and Laurent Sagart. 2014. Old Chinese: a new reconstruction. Oxford: Oxford University Press.

Baxter, William H. III. 1992. A Handbook of Old Chinese Phonology. Trends in Linguistics, Studies and Monographs 64. Berlin: Mouton de Gruyter.

Benedict, Paul K. 1972. Sino-Tibetan: a conspectus. Cambridge: Cambridge University Press.

Coblin, Weldon South. 1986. A Sinologist's Handlist of Sino-Tibetan Lexical Comparisons. Steyler Verlag.

Gong, Hwang-cherng. 1995. The System of Finals in Proto-Sino-Tibetan. In The Ancestry of Chinese, ed. William S-.-Y. Wang: 41-92. Journal of Chinese Linguistics Monograph Series.

Handel, Zev. 2002. Rethinking the medials of Old Chinese: Where are the r's? Cahiers de Linguistique - Asie Orientale 31.1:3-32.

Handel, Zev. 2008. What is Sino-Tibetan? Snapshot of a Field and a Language Family in Flux. Language and Linguistics Compass 2/3:422-441.

Hill, Nathan W. 2012. The six vowel hypothesis of Old Chinese in comparative context. Bulletin of Chinese Linguistics 6:1-69.

Hill, Nathan W. 2014a. Cognates of Old Chinese *-n, *-r, and *-j in Tibetan and Burmese. Cahiers de linguistique - Asie orientale 43:91-109.

Hill, Nathan W. 2014b. Some Tibetan verb forms that violate Dempsey's law. Revue d'Etudes Tibétaines 29:91-101.

Hill, Nathan W. 2014c. Tibeto-Burman *dz- > Tibetan z- and Related Proposals. In Studies in Chinese and Sino-Tibetan Linguistics, ed. Richard VanNess Simmons and Newell Ann Van Auken: 167-178. Taipei, Institute of Linguistics, Academia Sinica.

Jacques, Guillaume. 2012. A new transcription system for Old and Classical Tibetan. Linguistics of the Tibeto-Burman Area 35.2:89-96.

Jacques, Guillaume. 2014a. Denominal affixes as sources of antipassive markers in Japhug Rgyalrong. Lingua 138:1-22.

Jacques, Guillaume. 2014b. Esquisse de phonologie et de morphologie historique du tangoute. Leiden: Brill. 
Kongren, Ramjee. 2007. Yakkha-Nepali-English dictionary. Kathmandu: Indigenous People Yakkha Organisation.

Li, Fang-kuei, and Weldon S. Coblin. 1987. A study of the Tibetan inscriptions. Nankang: Institute of History and Philology, Academia Sinica.

Sagart, Laurent. 1999. The roots of Old Chinese. Amsterdam: Benjamins.

Sagart, Laurent. 2014. A Note on Tibeto-Burman Bone Words and Chinese Pitch-Pipes. In Studies in Chinese and Sino-Tibetan Linguistics, ed. Richard VanNess Simmons and Newell Ann Van Auken: 178-183. Taipei, Institute of Linguistics, Academia Sinica.

Schuessler, Axel. 2009. Minimal Old Chinese and Later Han Chinese: A Companion to Grammata Serica Recensa. Honolulu: University of Hawai'i Press.

Starostin, Sergej Anatoljevich. 1989. Реконструкция древнекитайской фонологической системы. Moskva: Nauka.

Sun, Wencai 孙文采. 1992. Explaining the character "shen" 释参. 人参研 究 2:38-41.

Tolsma, Gerard Jacobus. 2006. A Grammar of Kulung. Leiden: Brill.

Xu, Kunyu 徐坤宇. 2011. Explaining the character "shen” 释 “参” . 语文 学刊 2:93-4.

Yakhontov, Sergei Ye. 1961. Сочетания согласных в древнекитайском языке. In Tруды XXV Международного конгресса востоковедов: 8995. 